\title{
Psychological problems of employees and students who work ON-LINE during the COVID19 Contingency
}

\section{Problemas Psicológicos de empleados y estudiantes que trabajan ON-LINE durante la Contingencia por COVID19}

\author{
ÁLVAREZ-GARCÍA, Mónica*†, GUERRERO-IBARRA Carlos and LARIOS-CALVA, Margarita \\ Universidad Tecnológica de Nezahualcóyotl
}

ID $1^{\text {st }}$ Author: Mónica, Álvarez-García / ORC ID: 0000-0003-3393-1277, Reasearcher ID Thomson: B-8810-2019, arXiv ID Author: TNNNZH-KUCB98
ID $1^{\text {st }}$ Coauthor: Carlos, Guerrero-Ibarra / ORC ID: 0000-0003-0958-7912, Reasearcher ID Thomson: B-8810- 2019
ID $2^{\text {nd }}$ Coauthor: Margarita, Larios-Calva / ORC ID: 0000-0002-2356-7419, arXiv ID Author: MARGARITA.LARIOSCA, CVU CONACYT ID: 1000061

DOI: $10.35429 /$ JCSI.2020.18.6.18.27

Received September 25, 2020; Accepted December 15, 2020

\begin{abstract}
The recent COVID 19 pandemic has brought with it a different way of living for all humanity, in this situation the way we communicate, socialize, shop and work among many other activities has changed considerably. The main objective of this research is to detect whether psychological problems such as: anxiety, depression, stress, exhaustion, and low concentration are factors that influence work and school deterioration in people who carry out activities ON-LINE. The investigation was realized in the municipality of Nezahualcóyotl during confinement at home due to the COVID-19 pandemic. The research results highlight that the main psychological problems presented by students and employees is "exhaustion" (27\%), followed by "low concentration" $(26 \%)$ and "stress" (18\%). More than half of the interviewees consider that the origin of these psychological problems are workloads and tasks; While $11 \%$ say it is due to the situation of the pandemic and in the presence of these problems, $89 \%$ say that they have caused the deterioration of their activities.
\end{abstract}

Problems, Psychological, ON-LINE

\begin{abstract}
La reciente pandemia por COVID 19 ha traído consigo una forma de vivir diferente para toda la humanidad; ante esta situación la forma de comunicarnos, socializar, comprar y trabajar entre otras muchas actividades, han cambiado considerablemente. La presente investigación tiene como objetivo central detectar si los problemas psicológicos como: ansiedad, depresión estrés, agotamiento, y baja concentración son factores que influyen en el deterioro laboral y escolar en las personas que realizan actividades ON-LINE. La investigación se desarrolló en el municipio de Nezahualcóyotl durante el confinamiento en su hogar por la pandemia de COVID-19. Los resultados de la investigación destacan que los principales problemas psicológicos que presentan los estudiantes y empleados es el "agotamiento" (27\%), seguido de la "poca concentración" (26\%), el "estrés" (18\%). Más de la mitad de los entrevistados consideran que el origen de estos problemas psicológicos son las cargas de trabajo y tareas; mientras que el $11 \%$ dice ser por la situación de la pandemia y ante la presencia de estos problemas el $89 \%$ dice que han sufrido enfermedades psicológicas, lo que provoca el deterioro de sus actividades.
\end{abstract}

Problemas, Psicológicos, ON-LINE

Citation: ÁLVAREZ-GARCÍA, Mónica, GUERRERO-IBARRA Carlos and LARIOS-CALVA, Margarita. Psychological problems of employees and students who work ON-LINE during the COVID19 Contingency. Journal of Computational Systems and ICTs. 2020. 6-18: 18-27

\footnotetext{
* Author Correspondence (e-mail: gmonica34@yahoo.com.mx)

$\dagger$ Researcher contributing as first Author.
} 


\section{Introduction}

Given the emergence of the COVID19 pandemic that originated in the country of China and spread to Mexico in April 2020, citizens have had to remain in confinement to avoid massive infections.

This confinement has brought with it that education and many work activities are carried out from homes and more than 8 months of working or studying at home (ON-LINE), some people have begun to suffer some psychological problems such as stress, depression, anxiety, low concentration and exhaustion among others. The main objective of this research is to know to what extent the population of students and workers of Ciudad Nezahualcóyotl have presented some of these symptoms to the detriment of their health, school and work performance.

It is worth mentioning that some people, when presenting the aforementioned psychological problems, do not give it the required importance, however they begin to decrease in their daily tasks or affect their personal relationships.

At the same time, it is very important to raise awareness and analyze ourselves as people if confinement is causing us some of these psychological problems and if it has any repercussions on school or work life. It is vitally important that they can be detected and treated in time, to help improve their emotional state and work or school performance.

This research can provide important information that supports municipal authorities and educational institutions to carry out social campaigns that help people improve their emotional state. In this sense, the following question arises:

What are the psychological problems that cause deterioration in work and school performance in people in their ONLINE activities who inhabit the municipality of Nezahualcóyotl during the COVID-19 pandemic?

Likewise, the following objectives are established in the investigation:

\section{General}

Detect if psychological problems such as: anxiety, depression, stress, exhaustion and low concentration are factors that influence work and school deterioration in people who carry out activities ON-LINE in the municipality of Nezahualcóyotl, during confinement at home due to the pandemic of COVID-19.

\section{Specific}

- Know which are the psychological problems that students and employees who carry out activities ON-LINE during confinement present the most.

- Detect the levels of stress, chronic exhaustion, anxiety, low concentration and depression caused by ON-LINE activities during confinement due to COVID 19.

- Detect factors external to work that cause lack of concentration in students and employees.

- Know which or which of the psychological problems (stress, chronic exhaustion, anxiety, low concentration and depression) are causing the deterioration in the performance of their ON-LINE activities.

- Know the type of stress (chronic or acute) students and employees consider to be presenting due to confinement at home during their ON-LINE activities.

- The following sections present the method, theoretical framework, results of applied research with a sample of 123 people, conclusions and bibliographic references.

\section{Method}

The study had a quantitative, descriptive and non-experimental approach, the data were analyzed through absolute and relative frequencies, in addition, in some cases statistical measures such as the mean were obtained, the variables were not manipulated to perform the analysis, only the findings of each of these. 
Universe and study population

It was taken as the universe of study Ciudad Nezahualcóyotl that according to data from the INEGI, 2015 census are 1,039,867 being the population to be investigated ages between 15 and 50 years that corresponds to $54.2 \%$ equivalent to 563,608 (INEGI Population and Housing Census 2015) and of There, they took students and employees who carry out activities ON-LINE that, according to the Study of Media and Device Consumption among Mexican Internet Users, Internet users against COVID$19,45 \%$ take online actions to work and $33 \%$ to study, resulting in 439,614 elements that make up the population under study.

\section{Sample}

To calculate the sample size, we worked with the formula for finite populations of the normal distribution curve, a confidence interval of $95 \%$ was used, probability in favor and against $50 \%$ and standard error of $9 \%$, giving as resulted in a sample of 123 items.

\section{Sampling}

To select the sample, the non-probabilistic "Snowball" was used, this is based on recommendations, an element is randomly selected and references to other elements are requested until the sample under study is selected. The information was collected through the Microsoft Teams platform, where the questionnaire was elaborated and edited with 18 questions, most of the questions were closed with nominal and ordinal scales. The compilation of the aforementioned information was carried out by the students of the Technological University of Nezahualcóyotl of the TSUDNM 42M group. The questionnaire was piloted and validated in advance with 20 people, once it was corrected and adapted, the link was taken and shared via email, Facebook and WhatsApp, among acquaintances to be answered.

Once the 123 questionnaires were answered and the data obtained on the platform, they were edited in EXCEL and the results tables and graphs were made to analyze the information.

\section{Theoretical framework}

In order to carry out this research, it was necessary to document various topics to understand what are the main psychological problems that the COVID19 pandemic is causing from the point of view of some specialists in the field in addition to what is confinement First it is important to mention that according to the International University of Valencia psychological problems are considered mental disorders and one in five people in the world suffers from one. The three most common are: anxiety disorder (AD), mood disorder (depression or mania, bipolar, dysthymia, premenstrual dysphoric or seasonal affective), with depression and finally externalization disorder; This includes attention deficit and hyperactivity disorder, oppositional defiant disorder, conduct disorder and intermittent explosive disorder (International University of Valencia, 2017)

Although for some medical specialists they also consider post-traumatic stress as a mental disorder. On the other hand, what is COVID19 is defined, according to the WHO (World Health Organization) it is the infectious disease caused by the coronavirus that has been discovered more recently. Both this new virus and the disease it causes were unknown before the outbreak broke out in Wuhan, China, in December 2019. Currently, COVID 19 is a pandemic that affects many countries around the world. (WHO 2020).

Within the measures to prevent the spread of this virus. The WHO has established the Public Health and Social Measures (MSPS) considering that they are crucial to contain the transmission of COVID-19 and reduce mortality from this disease.

MSPS include those related to personal protection (such as hand washing, protection against coughing and sneezing, and the use of a mask); environmental ones (such as cleaning, disinfection and ventilation); surveillance and response (including contact tracing, isolation and quarantine); physical distancing (eg, limiting the number of people gathered, maintaining distance in public places or workplaces, internal mobility restrictions); and those related to international travel. (WHO 2019) 
In this sense, confinement refers to isolation or quarantine that was one of the measures that was established at the beginning of the pandemic, this is how the Educational Institutions of the Country decided to suspend classes in April 2020 and start online education, in the same way, many companies also implemented the Home Office work strategy.

So far they have already been working on education and online work for approximately 9 months to try to maintain social isolation.

Online distance education is conceptualized as the teaching / learning activities in the cognitive and / or psychomotor and affective domains of an individual learner and a support organization. It is characterized by non-contiguous communication and can be carried out anywhere and at any time, which makes it attractive to adults with social and professional commitments. On the other hand, Keegan (1988, p. 30) distinguishes it from other modalities by: a) the physical separation between teacher and students; b) by the existence of an educational institution that orders the process; c) by the use of communication means in student-teacher communication (means that have evolved over time and that some of them must necessarily be two-way); and, finally, d) because it is an industrialized form of education, which radically differentiates it from other more "artisanal" educational modalities. Holmberg (1989, p. 168) In the same way, the Home-Office is defined as the telework possibilities that we currently have thanks to new technologies that have allowed many professionals to make their home their own workplace, their office. This is what in English is called home office, a term that is also used in Spanish.

Continuing with the previous line of language, in our reality the home office has another meaning: the central headquarters (home as home) of a company that has several headquarters, buildings or delegations. In this sense, home office would mean the place where the highest management positions work, and where global decisions are made.

Home office is made up of two words: home, which means "home", and office, which means office.
One of the main problems that is presented by school and work is stress

Orlandini (1999), following the tradition that conceives stress as excessive tension, points out that "from preschool grades to postgraduate university education, when a person is in a learning period they experience tension. This is called academic stress, and it occurs both in individual study and in the school classroom " (Barraza, 2004, p. 143).

Along the same lines, Caldera, Pulido and Martínez (2007) define academic stress as that which is generated by the demands imposed by the educational environment. Consequently, both students and teachers can be affected by this problem. However, we are going to focus on the academic stress of the students.

On the other hand, there is a psychosocial approach to academic stress, which emphasizes the psychosocial factors that can cause it, and which conceives it as: the discomfort that the student presents due to physical, emotional factors, whether of an interrelational or intrarelational nature, or environmental that can exert significant pressure on individual competence to face the school context in academic performance, metacognitive ability to solve problems, loss of a loved one, taking exams, relationship with peers and educators, search for recognition and identity, ability to relate the theoretical component to the specific reality addressed (Martínez and Díaz, 2007, p. 14).

And work stress, where the growing pressure in the work environment can cause the physical and / or mental saturation of the worker, generating various consequences that not only affect health, but also their immediate environment since it generates an imbalance between work and the personal. Its symptoms are: Emotional (Anxiety, fear, irritability). Behavioral (decreased productivity, making mistakes). Cognitive (Difficulty concentrating, confusion, forgetfulness, reduced ability to solve problems. Physiological (Contracted muscles, headache, back or neck problems, upset stomach, fatigue, infections, palpitations, rapid breathing, increased pressure blood pressure, exhaustion, increased risk of obesity and cardiovascular problems, memory impairment, sleep problems (IMSS, Instituto Mexicano del Seguro Social). 
With confinement some of the problems that have been presented are: feeling overwhelmed, that is, an anxious clinical condition. Even if it lasts a little longer, clinical related to depression: having less desire to do things, to enjoy a little less. If anxiety becomes chronic, there may be symptoms of low spirits. There are also people with deceased relatives these days and they have not been able to say goodbye to them. These are more critical situations that can lead to a greater increase in anxiety or depression, and even turn into acute stress syndromes; a maximum anxiety caused by impotence in the face of the situation. If these symptoms last over time, it can cause certain mental illnesses, related to anxiety and depression (Ruiz M, 2020)

Brooks et al. (2020). In a recent review, they exposed the psychological impact of quarantine on some epidemics that have plagued humanity so far in the 21st century (SARS-CoV, MERS-CoV, A / H1N1 flu and Ebola), noting that this measure has had a negative effect on people's mental health. The authors described a higher prevalence of mental symptoms, such as distress, anxiety, sadness, low self-esteem, anger, rage, isolation, low mood and insomnia, and the appearance of disorders such as depression, anxiety, obsessive-compulsive disorder , post-traumatic stress and suicide, among others.

These mental consequences are the result of the stressors associated with quarantine and can be extrapolated to the context of the current COVID-19 pandemic. Among the stressors are the long duration of the quarantine, frustration, boredom, loneliness, fear of contracting the disease or infecting someone, lack of information, lack of sufficient supplies (medicine and food), financial losses, the stigma of discrimination, economic imbalance or the processing of a grief without culturally learned rituals to be able to watch over and fire the family member, among others. (Jordan R.E et. Al. 2020).

These problems have arisen in people due to quarantine and confinement; conditions that have caused notable changes in their habits and that have led them to implement a work or study method adapting their environment (space, time, lighting, furniture and resources in general) to fully and efficiently comply with their activities
However, it is important to mention that the study refers to the psychological problems that students and employees who are working online are having, which is the central objective of the research, to have a status of the part of the population that in Mexico is carrying out these activities, the "Study of Media and Device Consumption among Mexican Internet Users was reviewed; The Internet user facing COVID19 ".

The following Graph describes that the $45 \%$ who carry out online activities, do it to work and $33 \%$ to take classes-courses (study).

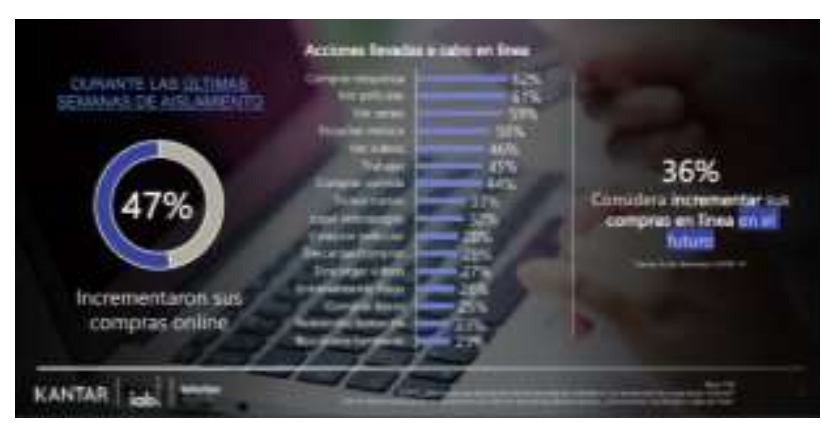

Graphic 1

Source: iab Mexico Televisa Digital. (2020), Study of Media and Device Consumption among Mexican Internet Users, The Internet user against COVID-19

According to the study, online actions during the COVID 19 pandemic have also brought the use of applications such as mail and online search engines, downloading of Apps: videos, food delivery service, video calls, increased frequency of purchases in online, diversification of categories and payments for services, listening to radio in traditional and online media, consumption of content on altruism and social causes in the face of contingency, online education, online transactions have accelerated that already presented an evolutionary trend, such as : banking transactions and payment of services and "Home Office", which was already in a growing trend and accelerates in the face of COVID-19.

The results show which are the psychological alterations-disorders that people are presenting the most as a result of academic and work-at-home activities, and that these data are useful to companies and institutions to implement actions-strategies that contribute to people to counteract these effects on personal health and improve their respective performance conditions. 


\section{Results}

As mentioned above, the research was carried out with a sample of 123 people from the municipality of Ciudad Nezahualcóyotl. with the objective of determining how the psychological problems caused by the confinement to which the population has been subjected due to COVID -19; have impacted on job or school performance.

Of the 123 people surveyed, 51\% correspond to males and $49 \%$ to females, as shown in the following Graphic.

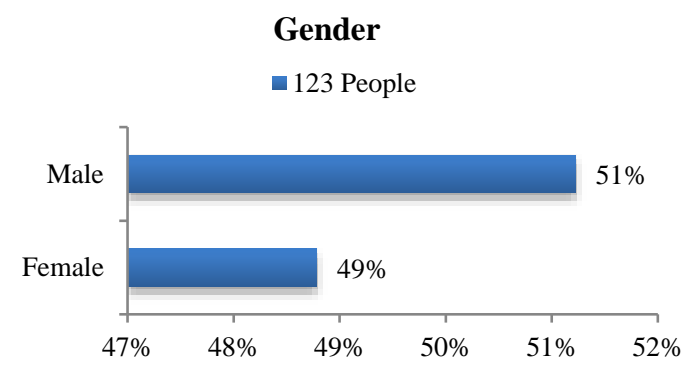

Graphic 2

$100 \%$ of the interviewees live in Ciudad Nezahualcóyotl and 37\% are workers and 63\% students.

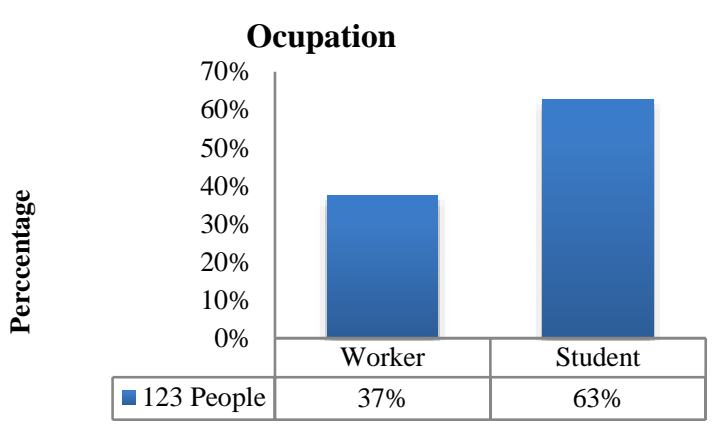

Graphic 3

The ages of the interviewees fluctuate between 15 and 50 years, with the highest percentage being 19 years $(24 \%)$ and 20 years with $11 \%$.

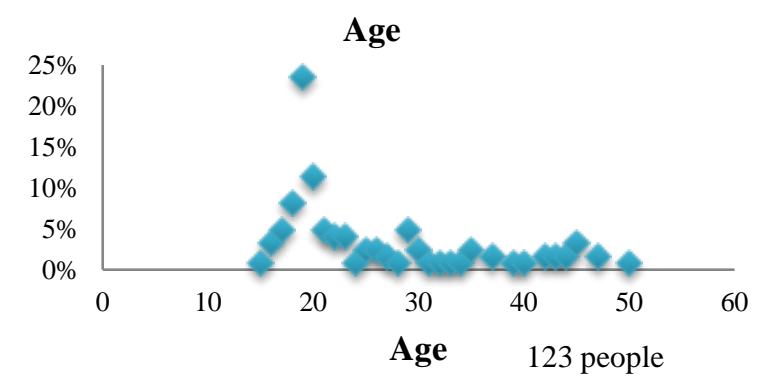

Graphic 4
During the period of the investigation, $100 \%$ of the respondents carried out their activities ON LINE. In relation to the problems they have suffered from confinement, exhaustion and poor concentration stand out, and thirdly stress, although it should be mentioned that the first two can also be the result of stress due to the different activities carried out $\mathrm{ON}$ LINE and being the most some of the time at home. See the following Graphic.

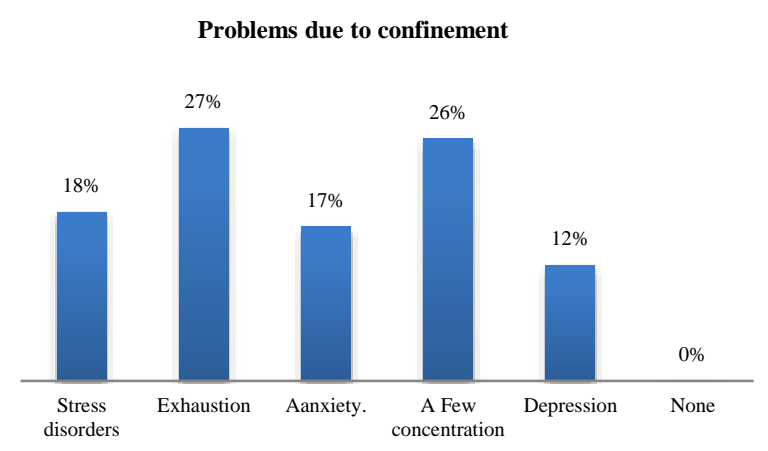

Graphic 5

Regarding the frequency with which they suffered psychological problems, more than half of those investigated (54\%) expressed having suffered them once a week.

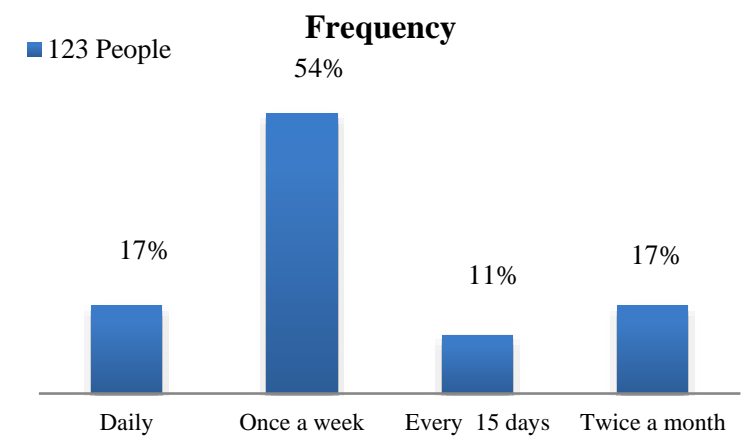

Graphic 6

The main reason why psychological problems occur, according to the interviewees, overload of work and tasks and the demands in these activities $(85 \%)$.

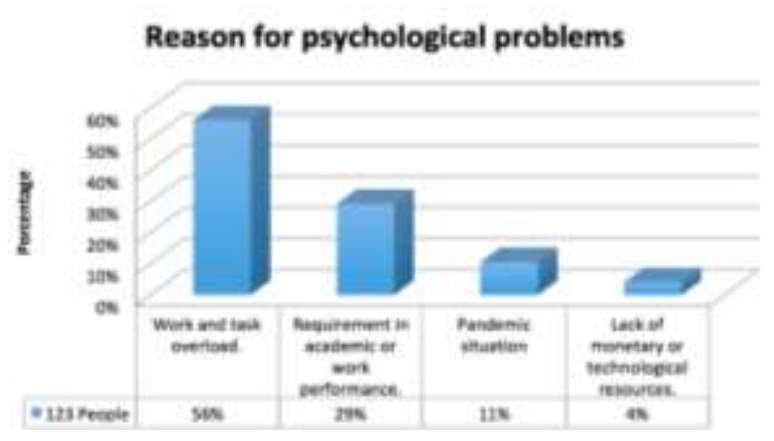

Graphic 7

ÁLVAREZ-GARCÍA, Mónica, GUERRERO-IBARRA Carlos and LARIOS-CALVA, Margarita. Psychological problems of employees and students who work ON-LINE during the COVID19 Contingency. Journal of Computational Systems and ICTs. 2020 
$89 \%$ expressed having suffered deterioration in the performance of their activities due to the psychological problems presented, especially due to exhaustion and stress as shown in the following Graphic.

Impairment due to psychological problems

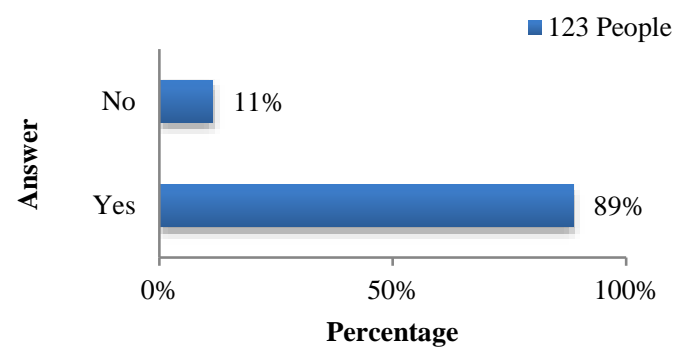

\section{Graphic 8}

In the investigation, they were questioned about the consequences suffered by the deterioration of their work and the main answers given were: low grades in students and penalties at work.

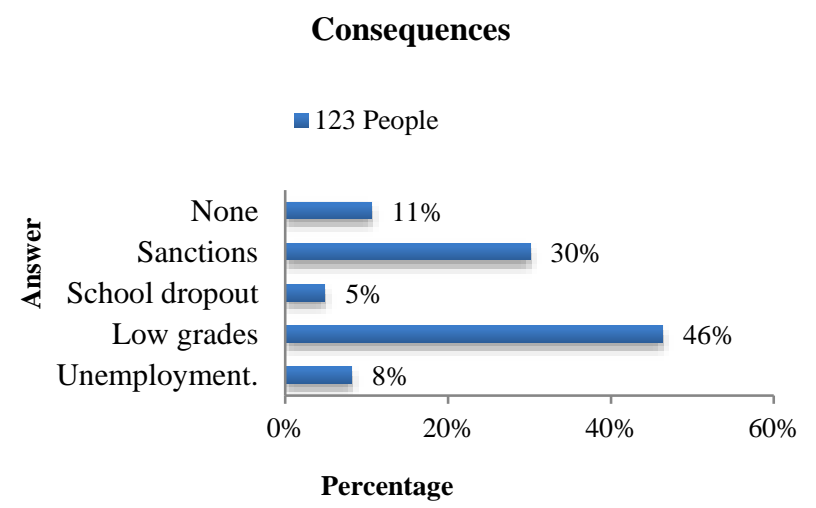

\section{Graphic 9}

Considering that stress is one of the main psychological problems that can affect activities in students and workers, they were asked the type of stress that has influenced during confinement and it was detected that 53\% chronic stress and only a third answered that none.

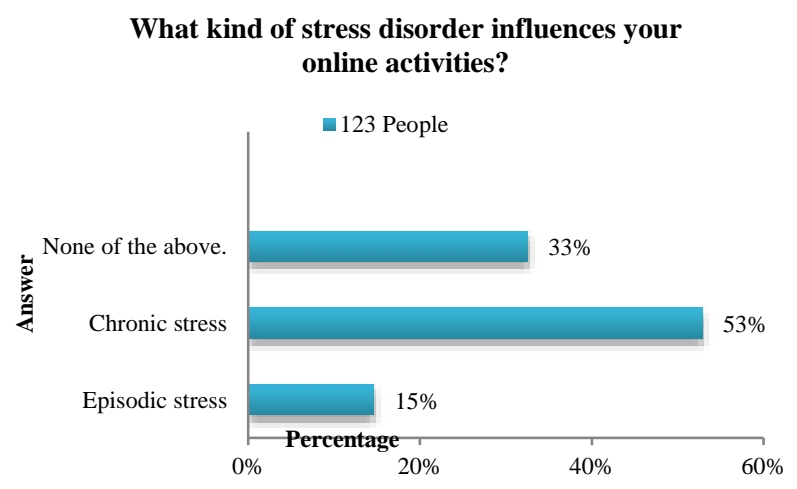

\section{Graphic 10}

ISSN-2444-5002

ECORFAN $^{\circledR}$ Todos los derechos reservados
In relation to the frequency of the problems presented, it is observed that more than half also answered that once a week and when obtaining the average, it gives 10 times a month.

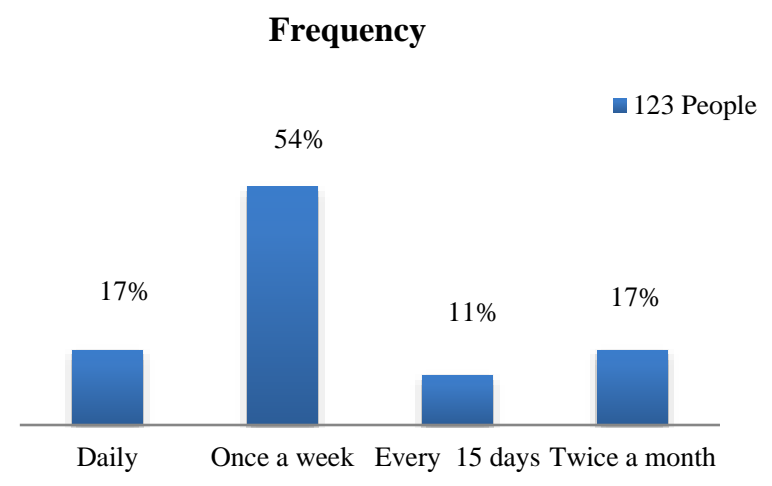

\section{Graphic 11}

The level of exhaustion due to confinement and work ON LINE, showed "Much" according to the average, as expressed by the respondents.

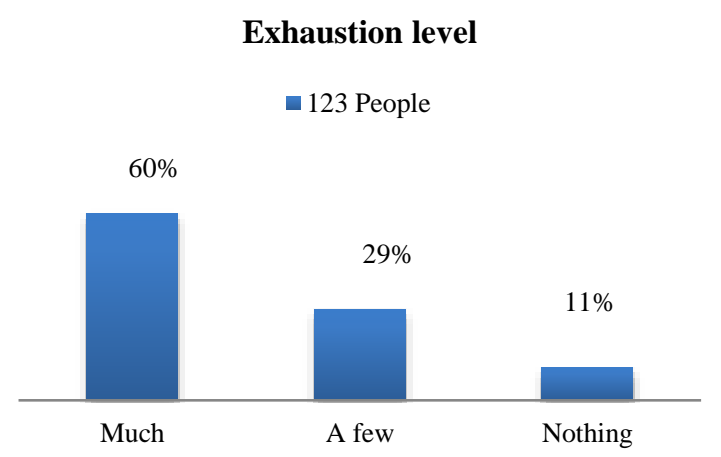

\section{Graphic 12}

According to irritability, 79\% answered that they have suffered from this problem.

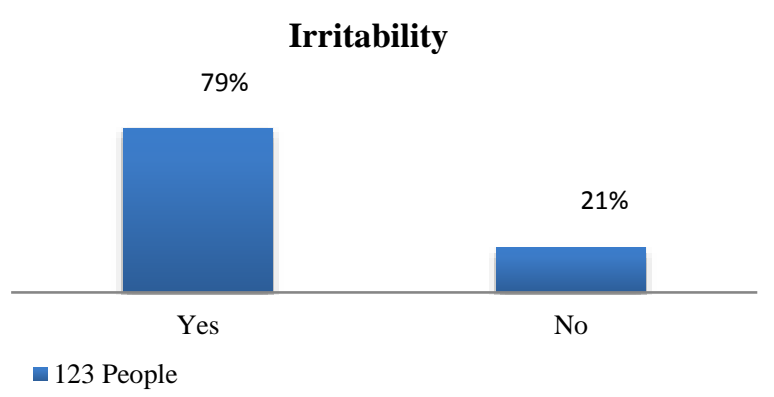

\section{Graphic 13}

With regard to anxiety and the average obtained, it can be said that this psychological problem has suffered "a little". 


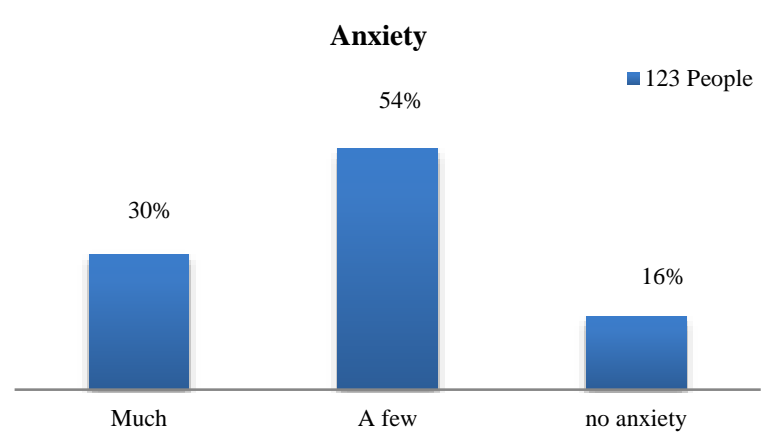

Graphic 14

Regarding the control of their emotions, opinions are very similar, let's say that half if they control them and the other half do not; as shown in the following Graphic.

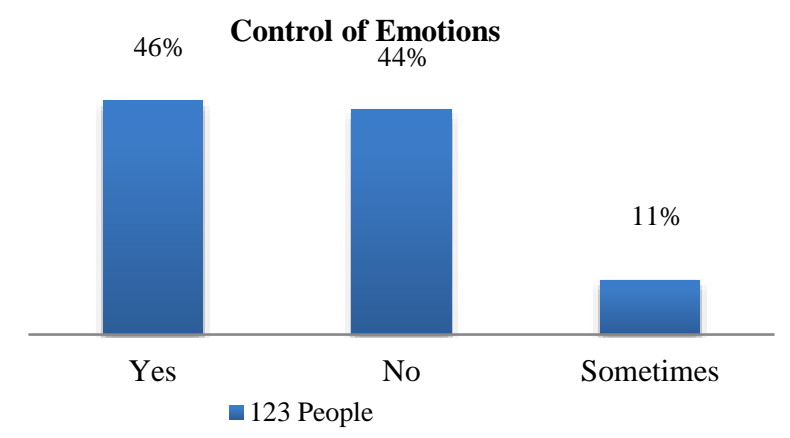

Graphic 15

Of the 123 people surveyed, half indicated that they suffered a lack of concentration in the confinement and the ONLINE work states that it is due to technical failures.

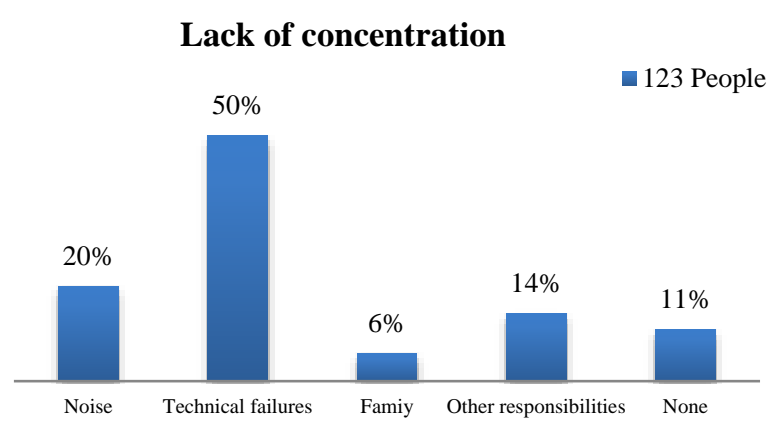

\section{Graphic 16}

$67 \%$ of the people surveyed responded that they had lost interest in their activities, due to ONLINE work.

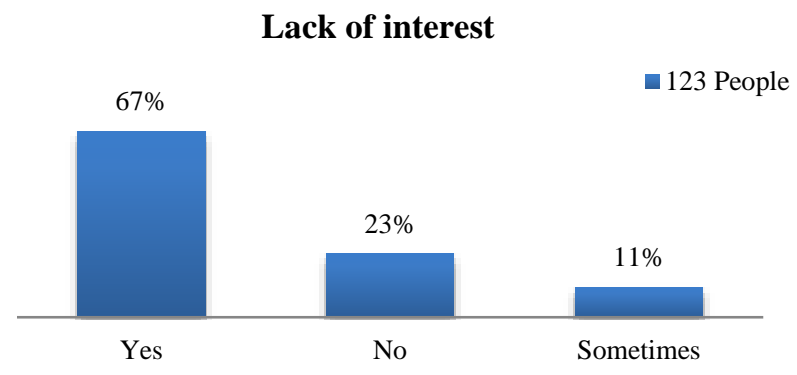

Graphic 17

ISSN-2444-5002

ECORFAN $^{\circledR}$ Todos los derechos reservados
And on the problem of depression, a quarter of those surveyed stated that they had presented a lot, while $41 \%$ of those surveyed had a low level, in such a way that when obtaining the average the indicative is "Little".

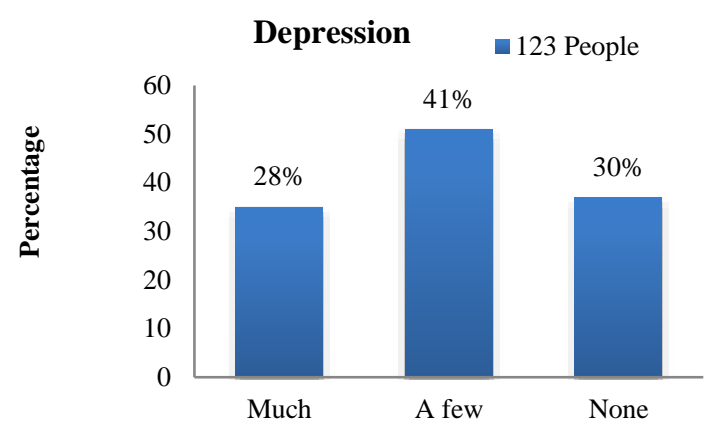

\section{Graphic 18}

Derived from depression, the respondents were asked if it influenced their isolation with the family, $37 \%$ expressed having suffered from this problem.

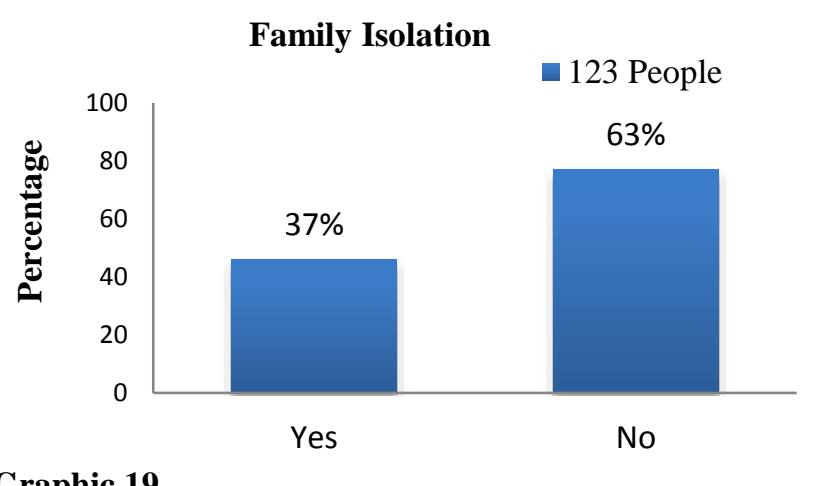

Graphic 19

\section{Conclusions}

Psychological problems are considered mental disorders, however for the research they were classified as problems. Those who suffer the most are anxiety and depression, with posttraumatic stress also being considered a disorder. According to WHO studies, those that are occurring the most in the pandemic caused by COVID19 are feeling overwhelmed, anxious and depressed due to confinement or health problems and deaths of family or friends. Considering that the general objective of the research was to detect if psychological problems such as: anxiety, depression, stress, exhaustion and low concentration are factors that influence work and school deterioration in people who carry out activities ON-LINE in the municipality of Nezahualcóyotl, during confinement at home due to the COVID-19 pandemic. 
According to the research carried out, the main psychological problems that students and employees who work ONLINE claim to have are exhaustion (27\%), low concentration (26\%) (symptoms of stress due to overwork) and with percentages less than $19 \%$ stress anxiety and depression. According to the averages (means) obtained in the analysis, the interviewees consider that they have a lot of exhaustion, little anxiety and little depression. But if you have a chronic stress 53\%. $79 \%$ answered having suffered irritability and $67 \%$ lack of interest to carry out their activities.

The psychological problems they have had; say they are overworked and demands on their performance, however less than half say they have control of their emotions.

Finally, it is concluded that all the psychological problems that they have presented if they are deteriorating the performance of their work and academic activities, 89\% answered that they were affected in this sense and as mentioned above it is having an impact on the exhaustion, lack of concentration and stress that is is giving in ONLINE activities during confinement due to the pandemic caused by COVID19.

\section{References}

Brooks S.K (2020), Webster R.K., Smith L.E., Woodland L., Wessely S., Greenberg N. The psychological impact of quarantine and how to reduce it: rapid review of the evidence. Lancet, DOI: 10.1016/s0140-6736(20)30460-8. (PMC free article) (PubMed) (Google Scholar).

iab.México Televisa Digital, (2020), Estudio de Consumo de Medios y Dispositivos entre Internautas Mexicanos, El internauta frente al COVID-19 extraído de: https://rdstationstatic.s3.amazonaws.com/cms/fi les/65507/1591034063Corte_COVID19_V_Publica.pdf.

IMSS, (Instituto Mexicano del Seguro Social,) Estrés Laboral, extraído de : http://www.imss.gob.mx/salud-en-linea/estreslaboral

INEGI. Encuesta Intercensal (2015), Tabulados México, Población. México. 2016 http://Inegi.gob.mx.
Jordan R.E., Peymane A., Cheng K.K. (2020), COVID-19: risk factors for severe disease and death. BMJ.;368:m1198. DOI: 10.1136/bmj.m1198. (PubMed) (Google Scholar).

Larios A., Bohorquez J., Naranjo J, Sáenz J., (2020), Impacto psicológico del aislamiento social en el paciente comórbido: a propósito de la pandemia COVID-19, extraído de: https://www.ncbi.nlm.nih.gov/pmc/articles/PM C7442894/

OMS, (2020), Organización Mundial de la Salud, Consideraciones para aplicar y ajustar medidas de salud pública y sociales en el contexto de la COVID-19, extraída de: https://apps.who.int/iris/bitstream/handle/10665 /336990/WHO-2019-nCoV-

Adjusting_PH_measures-2020.2-spa.pdf

OMS, (2019), Organización Mundial de la Salud, Preguntas y respuestas sobre la enfermedad por coronavirus (COVID-19), extraída de: https://www.who.int/es/emergencies/diseases/n ovel-coronavirus-2019/advice-for-public/q-acoronaviruses?gclid=Cj0KCQiAw_H-BRDARIsALQE_2NkizfRUY142w51pXwWqGNWVO5AFOp9j9Ez_JJOztibed6xFZ G0gUaAnVtEALw_wcB

Ruiz M., (2020), Gaceta Médica, Secuelas psicológicas de la pandemia "Nos preparamos para la cuarta ola, los problemas sobre la salud mental". extraído de https:/gacetamedica.com/profesion/secuelaspsicologicas-pandemia-nos-preparamos-parala-cuarta-ola-los-problemas-sobre-la-saludmental/ 17/ 12/2020

Universidad Internacional de Valencia (2017), ciencias de la salud, Problemas psicológicos más comunes, extraído de: https://www.universidadviu.com/co/actualidad/ nuestros-expertos/los-problemas-psicologicosmas-comunes 